\title{
Nature and ecological implications of algal pigment diversity on the Molenplaat tidal flat (Westerschelde estuary, SW Netherlands)
}

\author{
Cathy H. Lucas*, Patrick M. Holligan \\ School of Ocean and Earth Science, University of Southampton, Southampton Oceanography Centre, European Way, \\ Southampton SO14 3ZH, United Kingdom
}

\begin{abstract}
Depth profiles of chlorophyll a (chl a), its degradation products, and accessory pigment markers from 5 sites with differing sediment properties highlighted the role of physical and biological processes in re-distributing microalgal biomass both horizontally and vertically around the Molenplaat tidal flat. Intermediate-scale distribution of chl a was highly correlated with sedimentological parameters, with biomass greatest at siltier sites. Fucoxanthin:chl a ratios of 0.35 to 1.60 indicated that the microphytobenthos community was dominated by diatoms in both silty and sandy sediments. Cyanobacteria (zeaxanthin) were also present, mainly in September. Other sources of algae came in the form of deposited water column material. Peridinin, $19^{\prime}$ hexanoyloxyfucoxanthin, and to a lesser extent chl $b$ were the main pigments, primarily found at silty sites. Between June and September, the relative amounts of accessory pigments increased suggesting that inputs of material from the water column occurred during this period. Although benthic and water column pigments were found in the surface layers of silty and sandy sites, there were pronounced differences in biomass and vertical distribution. At sandy sites, homogenous vertical distributions of chl a in the upper $2 \mathrm{~cm}$ of sediment, together with low phaeopigment levels and the absence of water colum pigments below the surface layer, suggest that accumulation of in situ and allochthonous sources of microalgae is insignificant. Material is subjected to a continuous cycle of burial and resuspension during each tidal cycle and through the action of bioturbators such as Arenicola marina. There was a pronounced peak in chl a biomass at the silty sites in June. Rapidly decreasing chl a over the top $1 \mathrm{~cm}$ suggests that degradation was more rapid than sediment mixing. Large amounts of phaeopigments were produced, with the relative contribution switching from phaeophytins (March/April) to phaeophorbides (September) as the role of the herbivorous community in chl a cycling became more significant. An increase in relative contributions of accessory pigments both at the surface and in deeper layers between spring and autumn suggest that silty sites are a sink for sedimenting algae from the water column during this time. During the late autumn-winter, chl a biomass and pigment diversity decreased considerably, coincident with reduced biological activity and increased physical mixing
\end{abstract}

KEY WORDS: Microphytobenthos - Diatoms - HPLC - Algal pigments - Degradation processes Sedimentation - Tidal flats

\section{INTRODUCTION}

Benthic microalgae (microphytobenthos) play an important role in the dynamics of shallow coastal systems, both as primary sources of organic matter for ecological and biogeochemical processes and as modi-

\footnotetext{
-E-mail: catherine.h.lucas@soc.soton.ac.uk
}

fiers of sediment dynamics. Many studies have described the biomass and taxonomic composition of microphytobenthos communities from intertidal flats (MacIntyre et al. 1996), often focusing on spatial and temporal distributions in relation to environmental variables such as sediment characteristics, light, salinity, wave exposure, and emersion period (Colijn \& Dijkema 1981, Sundbäck 1984, Oppenheim 1988, Santos et al. 1996). However, when used alone, cell counts 
and standard chlorophyll a (chl a) measurements only give limited information on the dynamic processes that occur on tidal flats.

High-performance liquid chromatography (HPLC) has been used for some time in phytoplankton research to identify and assess both community composition and ecological processes (Millie et al. 1993) such as physiological status, material flux and sedimentation, and grazing by zooplankton (Vernet \& Lorenzen 1987. Levinton \& McCartney 1991, Barlow et al. 1993a, Head \& Horne 1993). This technique can also be applied to benthic microalgal communities to answer similar questions relating to micraalgal community composition and processes occurring in the sediment and sediment-water interface (Riaux-Gobin et al. 1987, Bianchi et al. 1993, Sun et al. 1994, Cariou-Le Gall \& Blanchard 1995).

This paper describes the algal pigment distribution on the Molenplaat tidal flat in the Westerschelde (SW Netherlands), a turbid and eutrophic well-mixed coastal plain estuary (Heip 1988). The estuary is heavily polluted, with a high load of organic and inorganic substances resulting in a highly heterotrophic system (Stoetaert \& Herman 1995). The microalgal community is neither $\mathrm{N}$ nor $\mathrm{P}$ limited. However, net pelagic photosynthetic production is relatively low due to the high turbidity in the water column (Kromkamp et al. 1992, Stoetaert et al. 1994), and on

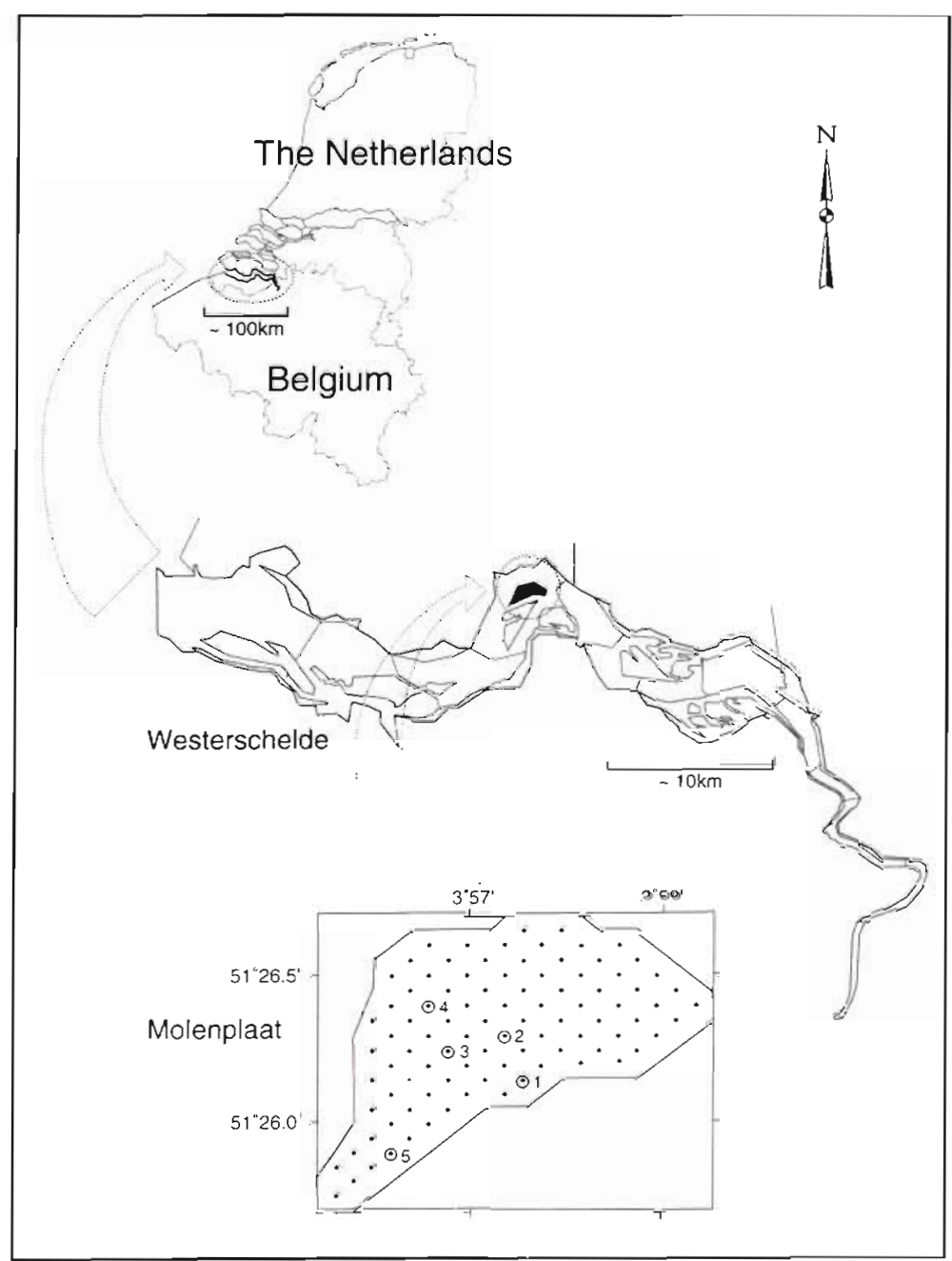

Fig. 1. Westerschelde estuary, showing the location of the Molenplaat tidal flat and the 5 sampling sites an estuary-wide scale, benthic primary production amounts to about $60 \%$ of pelagic primary production (Stoetaert \& Herman 1995). The microphytobenthos assemblage has been described for the estuary, and is dominated by diatoms for most of the year (Sabbe \& Vyverman 1991, Sabbe 1993), with summer inputs of cyanobacteria and euglenoids (Barranguet et al. 1997). This research into al.gal pigments forms part of a multidisciplinary project, ECOFLAT, which aims to study the processes important for carbon and nutrient cycling within a tidal flat ecosystem, and between the tidal flat and surrounding estuary

\section{MATERIALS AND METHODS}

Study area. The Molenplaat tidal flat, located in the mid-region of the Westerschelde estuary was chosen as the study area (Fig. 1). Based on a seasonal survey carried out in 1995, 5 sampling sites were selected, each one characterised by different physical properties (Table 1) and associated macrofauna communities. Site 2, located in the central region of the flat, experiences summer silt accumulation. Sites 4 and 5 are more sandy, particularly Site 5 , which is located in a high energy (megaripples) region of the Molenplaat. Sites 1 and 3 are intermediate in nature. Site 2 is dominated by the benthic suspension feeders Cerastoderma edule and Mya arenaria, although it also has a significant population of the head-down deposit feeder Heteromastus filiformis. Sites 1, 3, and 4 are dominated by deposit-feeding macrofauna communities, in particular Arenicola marina, Macoma balthica, and $H$. filiformis (NIOO Progress Report 1996).

Sampling. Sampling was carried out at all 5 sites during field campaigns in June and September 1996 and 1997, and at Sites 2 and 4 on a monthly basis dur- 
Table 1. Sediment characteristics from 1995 (water and AFDW are mean of 1996 and 1997). DW $=$ dry weight, AFDW $=$ ash free dry weight

\begin{tabular}{|c|c|c|c|c|c|c|c|c|c|c|}
\hline & \multicolumn{2}{|c|}{ Site 1} & \multicolumn{2}{|c|}{ Site 2} & \multicolumn{2}{|c|}{ Site 3} & \multicolumn{2}{|c|}{ Site 4} & \multicolumn{2}{|c|}{ Site 5} \\
\hline & Jun & Sep & Jun & Sep & Jun & Sep & Jun & Sep & Jun & Sep \\
\hline Mean grain size $(\mu \mathrm{m})$ & 77.02 & 147.08 & 37.62 & 58.54 & 193.99 & 167.47 & 228.35 & 175.58 & 178.52 & 159.97 \\
\hline$\%$ medium sand & 2.56 & 8.59 & 0.22 & 0.21 & 14.06 & 8.84 & 20.22 & 5.62 & 4.49 & 3.71 \\
\hline$\%$ fine sand & 23.97 & 50.59 & 7.03 & 16.88 & 67.55 & 64.01 & 71.64 & 29.81 & 86.91 & 79.42 \\
\hline$\%$ very fine sand & 19.00 & 17.65 & 14.69 & 27.58 & 6.80 & 11.62 & 3.96 & 6.54 & 4.90 & 6.01 \\
\hline$\%$ silt & 54.47 & 23.17 & 78.07 & 55.33 & 11.59 & 15.54 & 4.19 & 8.04 & 3.71 & 10.87 \\
\hline$\%$ AFDW (of DW) & 2.11 & 1.70 & 4.78 & 5.36 & 1.91 & 2.20 & 0.87 & 0.74 & 0.71 & 0.96 \\
\hline$\%$ water (of DW) & 32.28 & 30.07 & 50.39 & 45.62 & 29.41 & 29.11 & 24.58 & 23.73 & 17.34 & 22.26 \\
\hline
\end{tabular}

ing 1997. Sediment cores for HPLC analysis were collected using $2.54 \mathrm{~cm}$ diameter cut-off syringes, and sectioned on-site. In June 1996, 4 cores were collected randomly and sectioned at $0-5,5-10,15-20,20-40$, and $40-60 \mathrm{~mm}$ depth intervals. The corresponding depth sections were then combined and analysed as one. For the remaining campaigns, between 4 and 6 cores were collected at fixed points along a linear scale, and sectioned at $0-2,2-4,4-6,6-10,10-15$, and 15-20 mm depth intervals. The cores were analysed individually. The sections were freeze-dried in the dark for 24 to $72 \mathrm{~h}$ (until dry) and stored at $-70^{\circ} \mathrm{C}$ for between 2 and 9 mo prior to analysis. Storage of sediments for this length of time did not significantly affect pigment concentrations (see also Gieskes \& Kraay 1983, Klein \& Riaux-Gobin 1991). For microscopic control, sediment samples for cell identification and enumeration were similarly cored and sectioned, and preserved with formaldehyde (ca $2 \%$ final concentration). At the same time as the sediment coring, surface scrapings of the sediment for water and organic content were collected using a metal spatula and placed in preweighed vials.

Sediment characteristics. Water and total organic (ash free dry weight, AFDW) contents of the surficial sediment was determined after oven drying at $60^{\circ} \mathrm{C}$ for 3 to $4 \mathrm{~d}$, followed by the loss on ignition at $500^{\circ} \mathrm{C}$ for $24 \mathrm{~h}$.

Plant pigment analysis (HPLC). Dried sediments $(0.5 \pm 0.1 \mathrm{~g})$ for HPLC analysis were ground and the pigments extracted in $10 \mathrm{ml}$ of $90 \%$ acetone. The samples were ultrasonicated for $30 \mathrm{~s}$ and centrifuged at $3000 \mathrm{rpm}(2000 \times \mathrm{g})$ for $15 \mathrm{~min}$. The supernatant was filtered through a $0.2 \mu \mathrm{m}$ Nyaflo membrane filter (Gellman). Pigments were determined by ion-impairing, reverse-phase HPLC, modified from Mantoura \& Llewellyn (1983), and described by Barlow et al. (1993b).

The mobile phase consists of a binary eluant system consisting of eluant A (80\% methanol, 20\% $1 \mathrm{M}$ ammonium acetate), and eluant B (60\% methanol, $40 \%$ acetone). Ammonium acetate acts as an ion-impairing agent. For the analysis, $700 \mu$ of $1 \mathrm{M}$ ammonium acetate is mixed with $500 \mu$ l of pigment extract for $0.2 \mathrm{~min} .100 \mu \mathrm{l}$ of the resulting mixture is then injected into a Perkin Elmer $5 \mu \mathrm{m} \mathrm{C-18} \mathrm{column}(25 \mathrm{~cm} \times 46 \mathrm{~mm}$ i.d.). A linear gradient from 0 to $100 \%$ eluant $\mathrm{B}$ is created for $10 \mathrm{~min}$, followed by an isocratic stop at $100 \%$ eluant B for $7.5 \mathrm{~min}$. A second gradient of $2.5 \mathrm{~min}$ is used to return to the initial condition of $100 \%$ eluant $A$. Separation of the pigments was achieved within 17 min. Dual channel detection was achieved with a SpectraSystem UV1000 detector set to $440 \mathrm{~nm}$ for absorbance, and a SpectraSystem FL3000 fluorescence detector set at excitation $410 \mathrm{~nm}$ and emission $670 \mathrm{~nm}$.

Pigments were identified by comparing their peaks and retention times with either commercially available standards, or monocultures with well-documented accessory pigment markers, such as Phaeodactylum tricornutum (Bacillariophyceae), Amphidinium carterae (Dinophyceae), Synechococcus sp. (Cyanophyceae), Euglena sp. (Euglenophyceae), and Emiliania huxleyi (Prymnesiophyceae). The main pigments and their retention times (Rt) used in this paper are chlorophyll $c 1+c 2$ (chl $c 1+c 2)(2.2)$, peridinin (2.9), fucoxanthin (4.3), 19'hexanoyloxyfucoxanthin (4,6), diadinoxanthin (5.6), diatoxanthin (6.6), zeaxanthin/lutein (6.8), chlorophyll $b$ (chl b) (9.3), chl a (10.3). $\beta$-Carotene (12.0) was identified, but its cosmopolitan presence in most algal groups negated it as a useful indicator for this work. Breakdown products of chl a were identified as chlorophyllide a (Rt 2.0 min), phaeophorbides (elute before chl a) and phaeophytins (elute after chl a). The phaeophorbides and phaeophytins were numbered in order of elution as phaeophorbide $a_{1}$ (2.9), phaeophorbide $a_{2}$ (4.7), phaeophytin $a_{1}(11.7)$, and phaeophytin $a_{2}(12.5)$ in accordance with Barlow et al. (1993b) and PlanteCuny et al. (1993). The ' $\alpha_{2}$ ' phaeopigments correspond to the 'a-like' phaeopigments of Hawkins et al. (1986) and Klein \& Riaux-Gobin (1991), and the pyrophaeopigments of King \& Repeta (1991) and Head \& Horne (1993). Copepod faecal pellets were used as standards to identify retention times. Peak areas were converted 
to concentrations using response factors calculated from standards and published extinction coefficients (Mantoura \& Llewellyn 1983).

Microalgae counts. Microscopic analysis of the sediment microalgae was carried out to provide a control for the HPLC data, rather than supply detailed taxonomic information. The preserved samples were diluted with distilled water and prepared for examination using Utermöhl's sedimentation technique. The chambers were scanned at $200 \times$ magnification using an inverted microscope (Leica DMIRB). Both 'live' cells and frustules were identified and enumerated.
Table 2. Inter-site differences in chl a biomass $\left(\mathrm{mg} \mathrm{m}^{-2}\right)$, in June and September 1996 and 1997. Numbers are p-values resulting from unpaired t-tests. (ns = not significant, $n d=$ not enough data for $t$-test, df ranges between 4 and 49 )

\begin{tabular}{|c|c|c|c|c|c|c|c|c|c|c|c|}
\hline \multicolumn{6}{|c|}{ June 1996} & \multicolumn{6}{|c|}{ September 1996} \\
\hline Site & 1 & 2 & 3 & 4 & 5 & Site & 1 & 2 & 3 & 4 & 5 \\
\hline 1 & - & ns & 0.05 & nd & nd & 1 & - & 0.001 & 0.05 & ns & 0.05 \\
\hline 2 & & - & 0.05 & nd & nd & 2 & & - & 0.01 & 0.001 & 0.001 \\
\hline 3 & & & - & nd & nd & 3 & & & - & ns & 0.05 \\
\hline 4 & & & & - & nd & 4 & & & & - & ns \\
\hline 5 & & & & & - & 5 & & & & & - \\
\hline \multicolumn{6}{|c|}{ June 1997} & \multicolumn{6}{|c|}{ September 1997} \\
\hline Site & 1 & 2 & 3 & 4 & 5 & Site & 1 & 2 & 3 & 4 & 5 \\
\hline 1 & - & 0.01 & ns & 0.01 & 0.001 & 1 & - & ns & ns & 0.01 & 0.001 \\
\hline 2 & & - & 0.01 & 0.001 & 0.01 & 2 & & - & 0.001 & 0.001 & 0.001 \\
\hline 3 & & & - & 0.05 & 0.001 & 3 & & & - & 0.001 & 0.001 \\
\hline 4 & & & & - & 0.01 & 4 & & & & - & 0.02 \\
\hline 5 & & & & & - & 5 & & & & & - \\
\hline
\end{tabular}

\section{RESULTS}

\section{Microalgal biomass and environmental parameters}

Distributions of chl $a$ and phaeopigments in the upper $2 \mathrm{~mm}$ of sediment of the Molenplaat varied temporally and spatially (Fig. 2). Apart from a few cases, differences in chl a between sites were statistically significant (Table 2). Overall, siltier sites $(1,2,3)$ had greater chl $a$ and phaeopigments than sandier sites
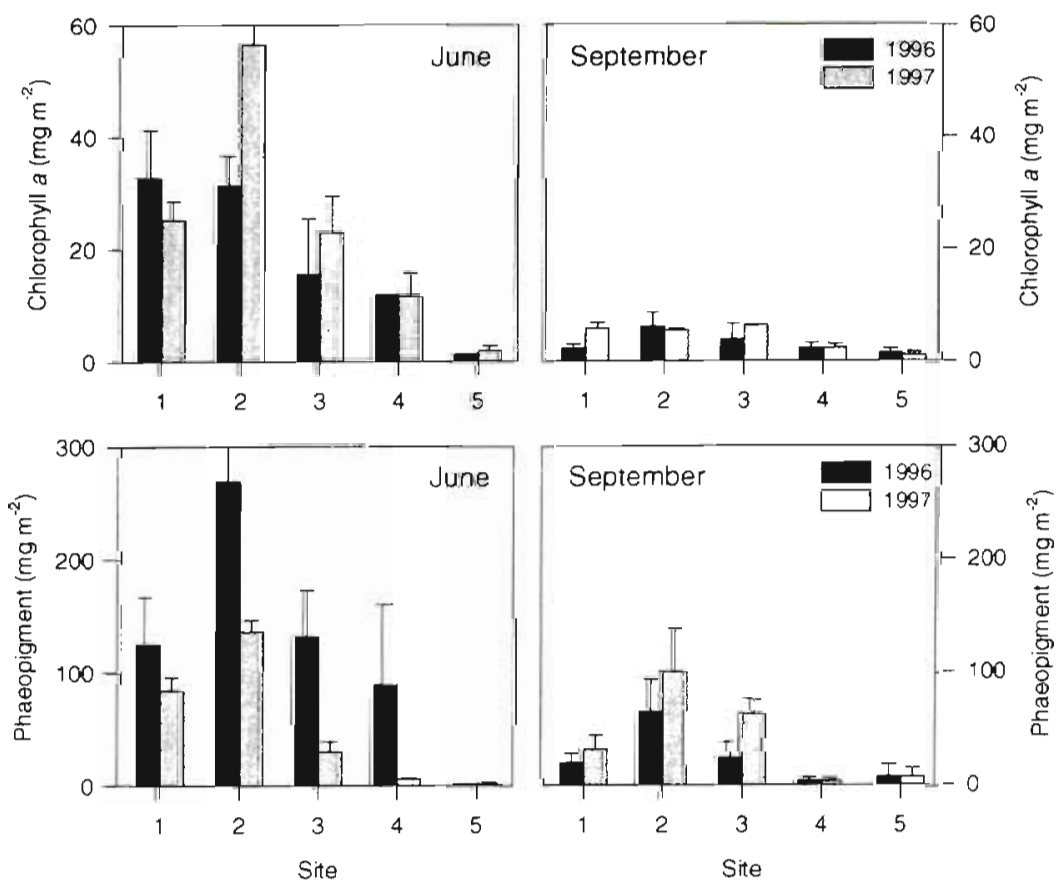

Fig. 2. Mean ( $\pm \mathrm{SD}$ ) chlorophyll $a$ and total phaeopigments in the upper $2 \mathrm{~mm}$ of sediment at Sites 1 to 5 in June and September 1996 and 1997
$(4,5)$, with mean values ranging from 1.1 and $1.3 \mathrm{mg}$ $\mathrm{m}^{-2}$ at Site 5 to 56.5 and $269.6 \mathrm{mg} \mathrm{m}^{-2}$ at Site 2 .

Chl a concentration was typically higher in June than September. The seasonal signal was very pronounced at Sites 1, 2 and $3(p<0.005, n=3$ to 24$)$, and slightly less so at Site $4(\mathrm{p}<0.01, \mathrm{n}=6)$. At Site 5 , there was no significant difference in mean chl a between June $\left(1.9 \mathrm{mg} \mathrm{m}^{-2}\right.$ ) and September $\left(1.1 \mathrm{mg} \mathrm{m}^{-2}\right)$. The seasonality at Sites 1,2 and 3 reflects the seasonal changes in environmental parameters at these sites, particularly mean grain size, silt, and AFDW contents (see Table 1). A degree of inter-annual variability was evident from this study, but this was only significant at Site 1 in September $(p<0.001, n=18)$, Site 2 in June $(\mathrm{p}<0.01, \mathrm{n}=4)$, and Site 3 in September $(p<0.10, n=24)$.

Causes of temporal and spatial differences were related to the surrounding environment using linear regressions. In June, chl a was positively correlated with silt $(\mathrm{r}=0.619, \mathrm{p}<$ 0.001 ) and negatively correlated with mean grain $(r=0.514, p<0.01)$ and median grain $(\mathrm{r}=0.496, \mathrm{p}<0.01)$ sizes. In September, chl a was positively correlated with water $(\mathrm{r}=0.358, \mathrm{p}<$ $0.001)$, AFDW $(r=0.368, p<0.001)$, silt $(0.312, p<0.01)$, and negatively correlated with mean grain ( $r=0.281, p<$ 0.01 ) and median grain ( $r=0.263, p<$ 0.01) sizes. There was no apparent relationship with sorting coefficient of the sediment, and none of the relationships between chl $a$ and sediment characteristics were valid for June and September combined. 
Surface variability at the centimetre scale (measured as coefficient of variation, \% CV, where $n=4$ to 28) was evident throughout the Molenplaat. Patchiness was greater in September (mean $48.4 \% \pm 34.7 \mathrm{SD}$ ) than in June $(31.8 \% \pm 27.0)$; and in phaeopigments $(49.8 \% \pm 40.2)$ compared with chl a $(32.3 \% \pm 19.0)$. As a general rule, coefficient of variation was lowest at Sites $2(23.8 \% \pm 15.0)$ and $1(25.9 \% \pm 11.4)$, and greatest at Site $5(87.7 \% \pm 45.1)$.

\section{Community composition}

Throughout the campaigns the carotenoid fucoxanthin was the dominant accessory pigment. Fucoxanthin, chl $c 1+c 2$, diadinoxanthin, and diatoxanthin are found in diatoms, as well as in the planktonic prymnesiophytes (also contain 19'hexanoyloxyfucoxanthin). Microscopical examination of preserved sediments confirmed the presence of benthic diatoms in significant numbers, particularly by members of the genera Nitzschia and Navicula. Ratios (by weight) between fucoxanthin and chl $a$ in the upper $2 \mathrm{~mm}$ of sediment ranged between 0.33 and 1.65, with overall mean values of 0.60 in June and 0.89 in September. Between-site differences were apparent, with siltier sites having higher fucoxanthin ratios than sandier sites (means 0.86 and 0.58 , respectively). The high energy sandy sites prevent accumulation of diatoms, and are likely to be composed of a mixed microalgal community which includes euglenoids and cyanobacteria. Although members of both groups were identified during microscopical examination, neither were found in particularly large numbers.

\section{Other sources of microalgal biomass}

Algal pigments other than those found in diatoms were also present on the Molenplaat. Overall, Sites 1, 2 and 3 had greater pigment diversity than Sites 4 and 5, and the relative amounts of pigments increased from June to September. Zeaxanthin was found at Sites 1 to 4 in June and at all sites in September. Chl $b$ was only present at Sites 1 to 4 in June in very low amounts $\left(<0.4 \mathrm{mg} \mathrm{m}^{-2}\right)$. Zeaxanthin is found in cyanobacteria, chlorophytes and prasinophytes, while chl $b$ is present in chlorophytes, prasinophytes, and euglenoids. Zeaxanthin:chl a ratios of up to 0.32 at Site 2, together with the virtual absence of $c h l b$, suggest that zeaxanthin is primarily identifying the presence of cyanobacteria, although macroalgae detritus cannot be discounted. The relative contribution of cyanobacteria to total chl a biomass is difficult to assess accurately because the slower degradation rate of zeaxanthin relative to chl a may bias ratios, but is estimated to be on the order of 5 to $10 \%$ at Sites 1 to 3 , and $1 \%$ at Site 4 . The presence of 'water column' pigments such as peridinin (dinoflagellates) and 19'hexanoyloxyfucoxanthin (prymnesiophytes) in the surface layers of the central, silty region of the Molenplaat indicate the presence of sedimented phytoplankton. The relative amounts of these pigments increased dramatically between June and September. For example, at Site 2, peridinin:chl a increased from 0.02 to 0.33 , while 19 'hexanoyloxyfucoxanthin: chl $a$ increased from 0.06 to 0.57 .

\section{Depth distributions of algal pigments}

Intact chl a was found to the maximum sampling depth of $6 \mathrm{~cm}$, well below the photic zone. Chl a below the photic zone is a potential source of primary production, and depth-integrated values of chl a (Table 3) give an indication of the amount of biomass that could become available at each site. At all the sites examined, changes in the temporal and spatial distributions of chl a were highly correlated with fucoxanthin ( $p<$ 0.01 to $0.001, n=6$ ), indicating that major changes in algal biomass are due to changes in diatom abundance. Apart from Site 4 in September, chl a decreased with depth at all sites (Fig. 3). This relationship was less significant in September. Overall, vertical distributions of chl a were fairly homogenous in September, with concentrations at 15 to $20 \mathrm{~mm}$ between 42.5 and $111.4 \%$ (mean $=70.4 \%$ ) of surface values. Similar spring and autumn chl a distributions were evident at the high energy Site 5. At the remaining sites in June the vertical structure was more heterogenous. At Site 2 for example, chl a concentration at 15 to $20 \mathrm{~mm}$ depth

Table 3. Mean (t SD) depth-integrated chl a and phaeopigments (Phaeops) values in $\mathrm{mg}$ for the upper $2 \mathrm{~cm}$ of sediment

\begin{tabular}{|c|c|c|c|c|c|}
\hline \multirow{2}{*}{ Year } & \multirow[t]{2}{*}{ Site } & \multicolumn{2}{|c|}{ June } & \multicolumn{2}{|c|}{ September } \\
\hline & & Chl a & Phaeops & Chl a & Phaeops \\
\hline \multirow[t]{5}{*}{1996} & 1 & $543.25(160.08)$ & $3040.20(1159.73)$ & $20.77(7.73)$ & $235.70(131.18)$ \\
\hline & 2 & $362.52(61.19)$ & $4155.41(1300.33)$ & $41.32(5.09)$ & $402.08(121.36)$ \\
\hline & 3 & $429.67(41.59)$ & $3919.21(333.00)$ & $24.40(5.61)$ & $264.51(120.53)$ \\
\hline & 4 & $191.29(0)$ & $1198.05(0)$ & $21.85(0)$ & $27.96(0)$ \\
\hline & 5 & $77.79(0)$ & $505.40(0)$ & $5.60(0)$ & $12.80(0)$ \\
\hline \multirow[t]{5}{*}{1997} & 1 & $100.37(0)$ & $545.06(0)$ & $50.91(0)$ & $388.63(0)$ \\
\hline & 2 & $184.58(0)$ & $1090.04(0)$ & $34.37(0)$ & $628.33(0)$ \\
\hline & 3 & $79.22(0)$ & $286.49(0)$ & $28.93(0)$ & $338.93(0)$ \\
\hline & 4 & $56.44(0)$ & $51.89(0)$ & $27.74(0)$ & $56.21(0)$ \\
\hline & 5 & $10.70(0)$ & $11.82(0)$ & $4.96(0)$ & $19.70(0)$ \\
\hline
\end{tabular}




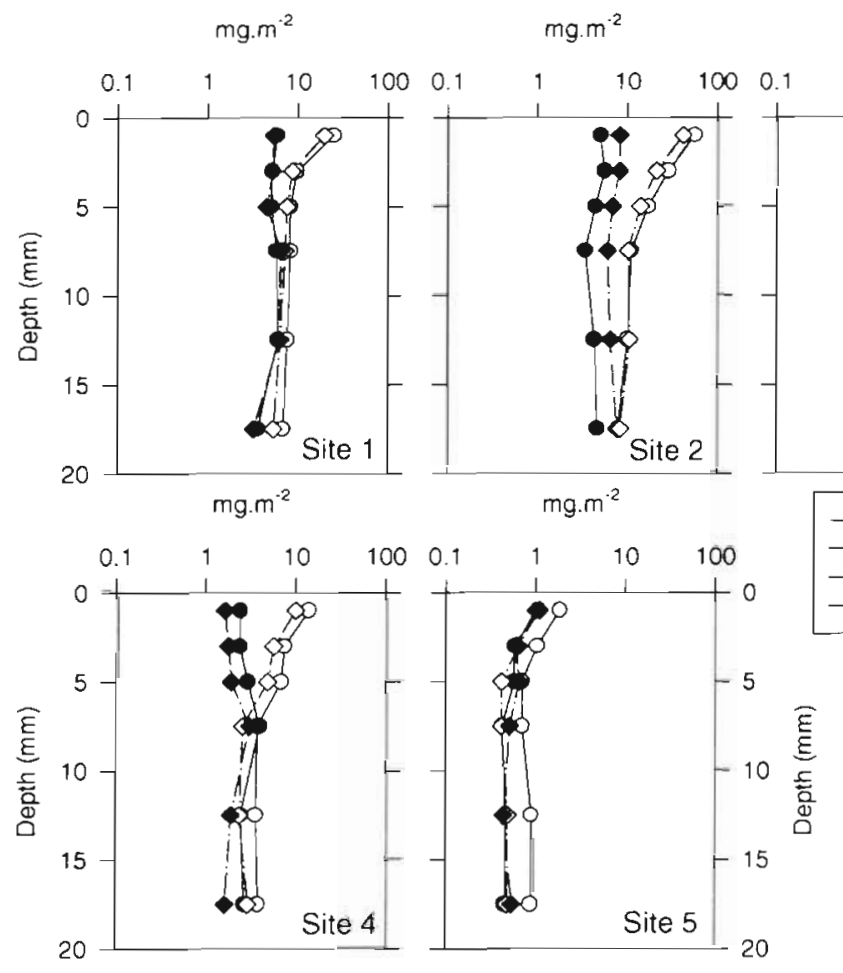

was only $14 \%$ of the surface value $(8.0$ compared with $56.5 \mathrm{mg} \mathrm{m}^{-2}$ ). At Sites 1.3 and 4 , chl a at 15 to $20 \mathrm{~mm}$ was 27 to $28 \%$ of surface values, but the slopes of the regressions were very different. For example, at 2 to $4 \mathrm{~mm}$ depth chl a was $38.5 \%$ of the surface value at Site $1,50.9 \%$ at Site 2 , and $72.2 \%$ at Site 3 . Because of the similar degradation rates of chl $a$ and fucoxanthin, ratios between the 2 pigments were consistent from the surface to $2 \mathrm{~cm}$ depth at all sites.

Differences in the physical environment and pigment degradation rates (reported in the literature) produce distinct vertical structuring of accessory pigment $m g \cdot m^{2}$

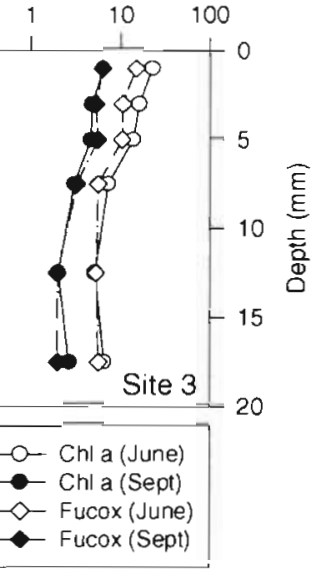

Fig. 3. Depth profiles of chl a and fucoxanthin at Sites 1 to 5 in June and September 1997

ratios. At one extreme, the high energy Site 5 was characterised by extremely poor pigment diversity and dominance of diatom indicators in both June and September (Fig. 4). There was no evidence of detrital or senescent phytoplankton, normally indicated by high chl c:chl a ratios, as well as chlorophyllide a. Indeed, chl $c 1+c 2$ was not sampled below $-5 \mathrm{~mm}$ depth, and the surface concentration is most likely due to the presence of diatoms produced in situ.

Site 4 was similar to Site 5, except that there were low-level, isolated patches of zeaxanthin, peridinin and $19^{\prime}$ hexanoyloxyfucoxanthin at depth. Chl $c 1+c 2$ was found to the maximum sampling depth of $2 \mathrm{~cm}$. In June there was a subsurface peak in the relative amount of chl $c 1+c 2$ between $\sim 4$ and $10 \mathrm{~mm}$ depth, with ratios typically $0.03-0.07$ at the surface, increasing to $0.08-0.12$. The subsurface peaks in chl $c 1+c 2$ : $\mathrm{chl}$ a could indicate senescence of the diatom bloom just below the photic zone. In September, chl $c 1+c 2$ was more homogenously distributed relative to chl a and fucoxanthin, with ratios $<0.05$.
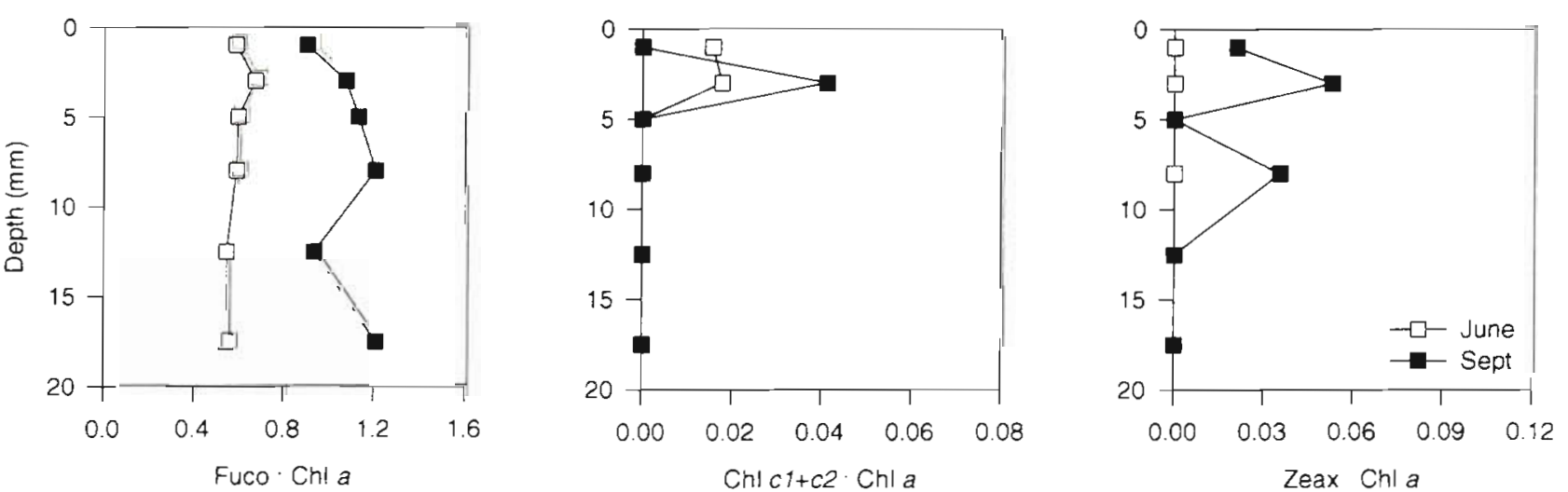

Fig. 4. Depth profiles of accessory pigment:chl a ratios at Site 5 in June and September 1997. Fuco = fucoxanthin, Zeax $=$ zeaxanthin 

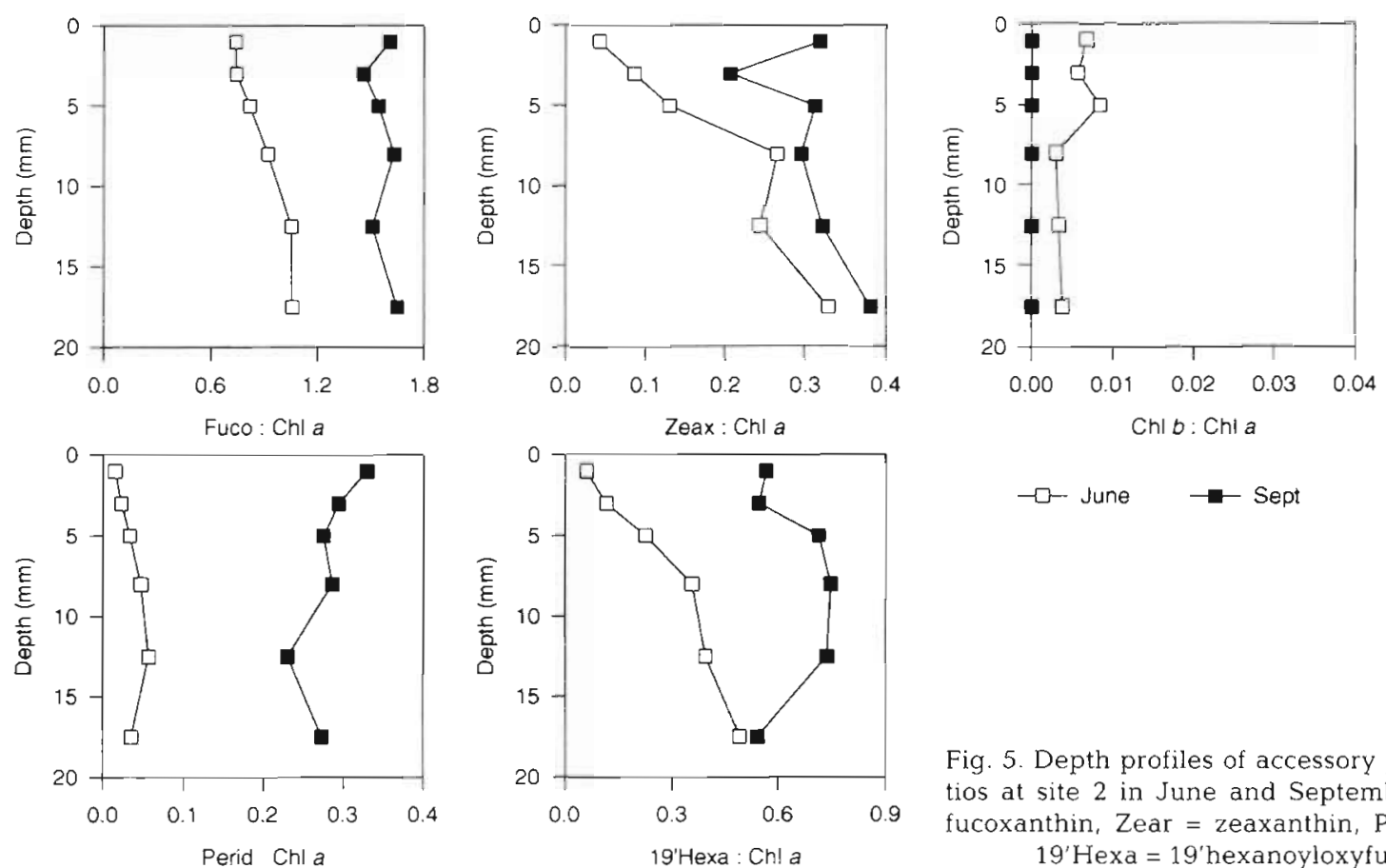

Fig. 5. Depth profiles of accessory pigment:chl a ratios at site 2 in June and September 1997. Fuco = fucoxanthin, Zear $=$ zeaxanthin, Perid $=$ peridinin, $19^{\prime}$ Hexa $=19^{\prime}$ hexanoyloxyfucoxanthin

Pigment diversity and changes in the vertical structure of accessory pigment ratios between June and September were particularly pronounced at Sites 1, 2 and 3. Fig. 5 illustrates these changes using Site 2 as the most extreme example. In June, increased 19 'hexanoyloxyfucoxanthin and zeaxanthin ratios with depth at the central sites may be caused by their slow degradation rates relative to the labile chl $a_{\text {, }}$ and high diatom production at the surface. Between June and September there was a general increase in the relative amounts of both short-lived (fucoxanthin, peridinin) and long-lived (19'hexanoyloxyfucoxanthin, zeaxanthin) pigments, and in September the vertical profiles of accessory pigment ratios generally became more homogenous

\section{Fate of microalgal biomass}

Phaeophorbides and phaeophytins were the major breakdown products of chl a on the Molenplaat. Chlorophyllide a was either absent or contributed an insignificant amount to total phaeopigments. The relative contributions of phaeophorbides and phaeophytins to total phaeopigments in the upper $2 \mathrm{~mm}$ of sediment is summarised in Table 4. Overall, phaeophorbides were the principal phaeopigment group. Although the distributions of chl a and its degradation products are closely related, several processes, including algal growth, senescence, photodegradation, bac-
Table 4. Relative contribution of the breakdown products phaeophorbides $\left(a_{1}+a_{2}\right)$ (Phorbides) and phaeophytins $\left(a_{1}+a_{2}\right)$ (Phytins) to total phaeopigments (Phaeops) in the upper $2 \mathrm{~mm}$ of sediment

\begin{tabular}{|c|c|c|c|c|c|}
\hline Site & Month & Year & $\begin{array}{l}\text { Phaeops } \\
\left(\mathrm{mg} \mathrm{m}^{-2}\right)\end{array}$ & $\begin{array}{c}\text { Phorbides } \\
(\%)\end{array}$ & $\begin{array}{c}\text { Phytins } \\
(\%)\end{array}$ \\
\hline \multirow[t]{2}{*}{1} & Jun & $\begin{array}{l}1996 \\
1997\end{array}$ & $\begin{array}{r}125.23 \\
83.76\end{array}$ & $\begin{array}{l}79.47 \\
73.39\end{array}$ & $\begin{array}{l}20.53 \\
26.61\end{array}$ \\
\hline & Sep & $\begin{array}{l}1996 \\
1997\end{array}$ & $\begin{array}{l}20.15 \\
24.95\end{array}$ & $\begin{array}{l}79.10 \\
78.15\end{array}$ & $\begin{array}{l}20.90 \\
21.85\end{array}$ \\
\hline \multirow[t]{2}{*}{2} & Jun & $\begin{array}{l}1996 \\
1997\end{array}$ & $\begin{array}{l}269.59 \\
136.02\end{array}$ & $\begin{array}{l}74.95 \\
67.05\end{array}$ & $\begin{array}{l}25.05 \\
32.95\end{array}$ \\
\hline & Sep & $\begin{array}{l}1996 \\
1997\end{array}$ & $\begin{array}{l}50.55 \\
85.62\end{array}$ & $\begin{array}{l}72.68 \\
85.47\end{array}$ & $\begin{array}{l}27.32 \\
14.53\end{array}$ \\
\hline \multirow[t]{2}{*}{3} & Jun & $\begin{array}{l}1996 \\
1997\end{array}$ & $\begin{array}{r}133.76 \\
29.98\end{array}$ & $\begin{array}{l}73.24 \\
71.51\end{array}$ & $\begin{array}{l}26.76 \\
28.49\end{array}$ \\
\hline & Sep & $\begin{array}{l}1996 \\
1997\end{array}$ & $\begin{array}{l}24.83 \\
52.58\end{array}$ & $\begin{array}{l}78.91 \\
84.21\end{array}$ & $\begin{array}{l}21.09 \\
15.79\end{array}$ \\
\hline \multirow[t]{2}{*}{4} & Jun & $\begin{array}{l}1996 \\
1997\end{array}$ & $\begin{array}{r}38.99 \\
6.12\end{array}$ & $\begin{array}{l}48.31 \\
61.59\end{array}$ & $\begin{array}{l}51.69 \\
38.41\end{array}$ \\
\hline & Sep & $\begin{array}{l}1996 \\
1997\end{array}$ & $\begin{array}{l}3.87 \\
2.62\end{array}$ & $\begin{array}{l}67.99 \\
72.21\end{array}$ & $\begin{array}{l}32.01 \\
27.79\end{array}$ \\
\hline \multirow[t]{2}{*}{5} & Jun & $\begin{array}{l}1996 \\
1997\end{array}$ & $\begin{array}{l}1.27 \\
1.28\end{array}$ & $\begin{array}{l}66.29 \\
60.51\end{array}$ & $\begin{array}{l}33.71 \\
39.49\end{array}$ \\
\hline & Sep & $\begin{array}{l}1996 \\
1997\end{array}$ & $\begin{array}{l}2.66 \\
5.29\end{array}$ & $\begin{array}{l}72.80 \\
71.70\end{array}$ & $\begin{array}{l}27.20 \\
28.30\end{array}$ \\
\hline
\end{tabular}



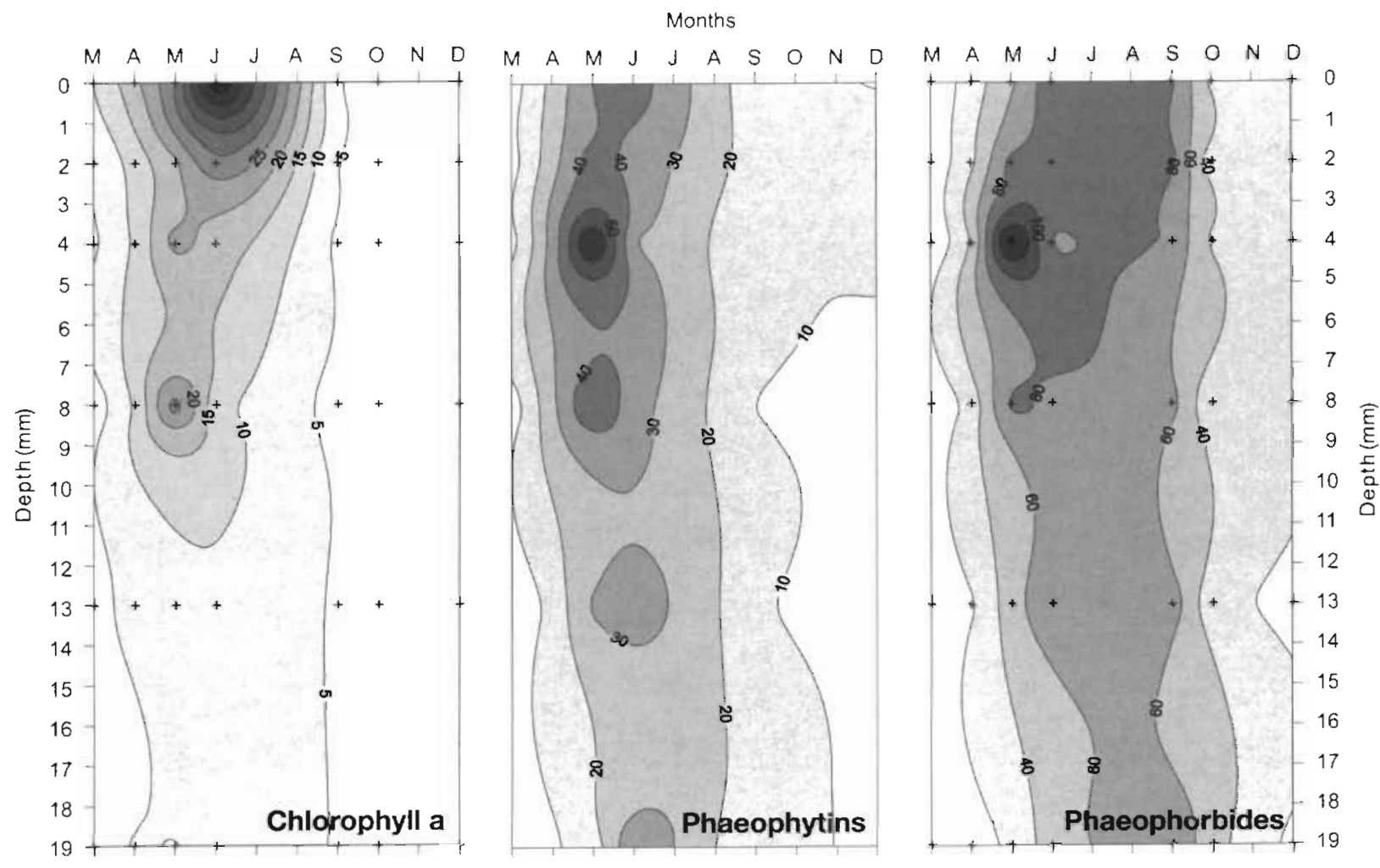

Fig. 6. Temporal change in the vertical distribution of chl a and its degradation products at Site 2
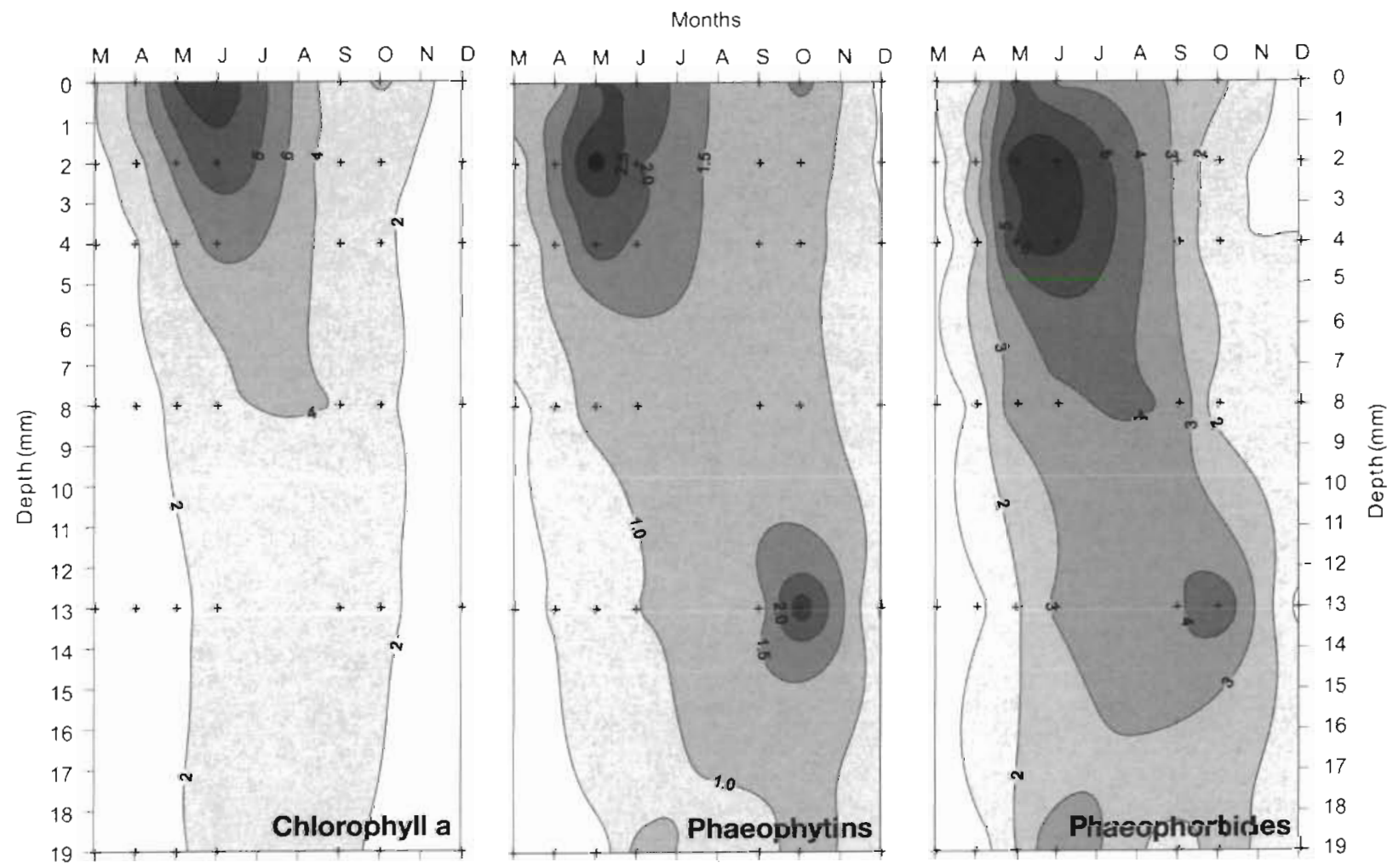

Fig. 7. Temporal change in the vertical distribution of chl a and its degradation products at Site 4 
terial degradation, and herbivore grazing, affect their relative concentrations. The differences in the fate of chl $a$ in silty and sandy sediments is demonstrated by following changes in the temporal vertical structure at Site 2 (Fig. 6) and Site 4 (Fig. 7).

At Site 2, the total amount of phaeopigments in the upper $2 \mathrm{~mm}$ increased throughout the spring from a minimum of $10.0 \mathrm{mg} \mathrm{m}^{-2}$ in March to $136.0 \mathrm{mg} \mathrm{m}^{-2}$ in June. From March through to May, phaeopigments displayed a subsurface peak at approximately $5 \mathrm{~mm}$, primarily due to phaeophorbides. Their contribution (particularly phaeophorbide $a_{2}$ ) to total phaeopigments increased from June to September throughout the upper $2 \mathrm{~cm}$, and during this time the phaeophorbide: chl a ratio also increased from $<6$ to $\sim 15$ to 20 . The ratio of phaeophytins to chl a was typically $<3$ from March through to September, increasing with depth. From September through to December, phaeophytin:chl a increased sharply to $>5$, becoming more vertically homogenous.

At Site 4, the temporal sequence in vertical distribution of the degradation products was similar to those at Site 2 , although the values were an order of magnitude lower. The relative contribution of phaeophorbides to total phaeopigments also increased through the course of the season to $70-76 \%$ in September. The ratios of phaeophytins and phaeophorbides to chl a were typically $<1$ and very patchily distributed in the vertical plane. Overall, phaeophytin:chl a ratios were greatest during the winter $(\sim 0.4$ to 1.2$)$. Phaeophorbide:chl a ratios were greatest in the summer ( 0.9 to 2.1$)$, which is significantly lower than those observed at Site 2.

\section{DISCUSSION}

\section{Sources of algal biomass}

Pigments in sediments can be derived from 3 sources: (1) microphytobenthos produced in situ; (2) sedimenting phytoplankton and tychoplankton; and (3) macroalgae detritus. HPLC and microscopic evidence clearly established the dominance of benthic diatoms within the microphytobenthos community of the Molenplaat. The carotenoid fucoxanthin was the dominant accessory pigment, which together with chl $c 1+c 2$, diadinoxanthin, and diatoxanthin is found in the Bacillariophyceae. Changes in temporal and spatial distributions of fucoxanthin were highly correlated with chl $a$. The predominance of diatoms confirms previous studies from the Westerschelde. Barranguet et al. (1997) observed that, in the more uniformly sandy NE region of the Molenplaat, there was a succession from diatoms in spring to cyanobacteria and euglenoids in summer, then back to diatoms in the autumn. The ben- thic diatom assemblage of the Westerschelde estuary has been examined taxonomically by Sabbe \& Vyverman (1991) and Sabbe (1993), including flats in close proximity to the Molenplaat. Species composition was dependent on sediment type, but was dominated by members of the genera Navicula, Nitzschia, Fragilaria, Acnanthes, and Opephora.

Of the accessory pigments identified on the Molenplaat, several are not found in diatoms. These include zeaxanthin, chl $b$, peridinin, and 19'hexanoyloxyfucoxanthin. The extremely low levels of $c h l b$ suggest that chlorophytes, prasinophytes and euglenoids were not an important component of microalgal biomass during the study period. The presence of zeaxanthin without chl $b$ is an indication of the presence of cyanobacteria rather than significant inputs of macroalgae detritus onto the flat. Macroalgae are not found on the Molenplaat, although seaweeds and saltmarsh plants such as Spartina townsendii are known to grow along the margins of the estuary (Sabbe 1993). The presence of 'water column' pigments such as peridinin and $19^{\prime}$ hexanoyloxyfucoxanthin in the surface layers indicate the presence of sedimented phytoplankton.

Interpretation of pigment ratios must be carried out with a degree of caution because of the large number of environmental and physiological factors that affect them. These include light regime, temperature, nutrient supply, and growth status. Nevertheless, they provide useful information on the taxonomy and status of microalgae populations. Overall, Sites 1,2 and 3 had greater pigment diversity than Sites 4 and 5. Between June and September, the relative amounts of the accessory pigments increased, particularly at Sites 1, 2 and 3 , suggesting that inputs of material from the water column occurred during this period. Fucoxanthin:chl a ratios also increased from an overall mean of 0.60 in June to 0.89 in September, and at Site 2 ratios were as high as 1.65. Fucoxanthin and chl a are reported to have similar half-lives (Abele-Oeschger 1991), and diatom monocultures have fucoxanthin: chi a ratios of $\sim 0.6$ to 0.8 (see Jeffrey et al. 1997). In the present study, fucoxanthin appeared to be more conservative than chl a. Although HPLC analysis cannot identify the source of diatoms, it is likely that accumulation of diatoms from both benthic and pelagic sources is occurring; some larger centric diatoms were found in the sediment samples. The behaviour of pigments in the water column prior to deposition is, however, complex. For example, Hurley \& Armstrong (1991) reported that water column fucoxanthin was substantially degraded prior to incorporation into sediments, whereas Leavitt \& Carpenter (1990) found that zooplankton processing, in addition to transforming chl a to phaeophorbides, may preferentially transport undegraded carotenoids to the sediment. 


\section{Re-distribution of microalgae within the tidal flat}

In agreement with many studies (Colijn \& Dijkema 1981, Sundbäck 1984, Lukatelich \& McComb 1986), the horizontal distribution of $\mathrm{chl} a$ was correlated with the abiotic environment. The correlations between chl $a$ and sediment characteristics such as grain size and silt content confirmed what many authors have reported: intermediate-scale distribution of microphytobenthos is governed by a combination of factors related to the degree of exposure to current speed and wave action (Sundbäck 1984). As a result, the physically stable, silty central region of the Molenplaat supported greater algal biomass than the more dynamic sandy regions.

Algal cells collected below the photic zone can photosynthesise when exposed to the light, and are therefore an important source of potential primary producers (Cadée \& Hegeman 1974). The presence of $\mathrm{chl}$ a below the photic zone ( 1 to $5 \mathrm{~mm}$ ) to depths of $>30 \mathrm{~cm}$ ( $6 \mathrm{~cm}$ sampling limit in present study) is caused by the balance between active migration of diatoms, and redistribution caused by hydrodynamic mixing by wave and current action, and bioturbation by deposit feeders (Cadée \& Hegeman 1974, Lukatelich \& McComb 1986, Fielding et al. 1988, Barranguet et al. 1997). Seasonal variation in profiles are due to changes in the relative importance of these processes (Sun et al. 1991). Across the whole of the Molenplaat, algae are being resuspended and deposited to and from the sediment surface during each tidal cycle. Although benthic and water column pigments were found in the surface layers of the silty and sandy sites, there were pronounced differences in biomass and vertical distribution. Differences in degradation rates between pigments, which are in turn affected by photo-oxidation, senescence, and grazing, can be used to identify the nature of organic cycling as defined by local physical and biological conditions.

In sandy regions, homogenous vertical distributions of chl $a$ in the upper $2 \mathrm{~cm}$ of sediment, together with the absence of 'water column' pigments below the surface layer, suggest that accumulation of both autochthonous or allochthonous sources of microalgae into the sediments is insignificant. High chl $c 1+c 2$ :chl a ratios, indicative of detrital or senescent algae, were not apparent. Indeed, chl $c 1+c 2$ was not sampled below $5 \mathrm{~mm}$ depth at Site 5 . With each tidal cycle, surface production is either resuspended into the water column by high current speeds or buried into the sediment during bedload transport (indicated by the presence of 1 to $2 \mathrm{~cm}$ high ripples). Diatoms living in sandy sites are primarily epipsammic in nature, and are transported attached to sand grains or other particles. Combined with the Arenicola marina population at
Site 4, which turns over the upper centimetres of sediment, the microalgae at this site are subjected to a continuous cycle of burial and resuspension, with losses approximately balanced by inputs. The high degree of small-scale patchiness in chl $a$ and phaeopigments at the surface of Sites 4 and 5 seems to be caused by a combination of wind/wave ripples and A. marina casts increasing bed roughness. This microtopography creates differences in current flow across the benthic boundary layer, resulting in suspended particles being deposited in pits and depressions (reviewed by Graf \& Rosenberg 1997). Increased patchiness at sandy sites is a similar observation to that of Sundbäck (1984), but is the opposite to that reported by Barranguet et al. (1997).

The import-export cycle of microalgae in the silty sediments was very different from the sandy sediments, and was subjected to far greater seasonality. During the early spring, relatively low chl a throughout the upper $2 \mathrm{~cm}$ suggests that either primary productivity is low or biomass from the photic zone is being buried and/or resuspended through tidal action. A peak in diatom biomass occurred during the late spring and early summer. During this time, the rapid decrease in chl a over the top 1 to $2 \mathrm{~cm}$ at Sites 1,2, and 3 suggests that degradation of chl a into phaeophorbides and phaeophytins was more rapid than sediment mixing, re-distributing chl a to depth (Sun et al. 1991). Large amounts of phaeopigments were produced, with the relative contribution switching from phaeophytins to phaeophorbides.

The increase in the relative contributions of accessory pigments such as fucoxanthin, peridinin, zeaxanthin, and 19'hexanoyloxyfucoxanthin between the spring and autumn suggests that Site 2 is a sink for sedimenting algae from the water column. The source of these algae could be phytoplankton and/or resuspended benthic diatoms from other regions of the Molenplaat. Lower current velocities over the central region of the flat, together with a sticky surface caused by diatom EPS (extracellular polymeric substances) and cohesive silt particles, cause material to become trapped into the sediment surface (Krumbein et al. 1994). The material produced or deposited at the surface becomes incorporated into the upper few centimetres of sediment during the summer and early autumn as more material is deposited on top. It is unlikely that the faunal community has a significant influence over the sediment mixing process, as these sites are not characterised by bioturbators. From September, the vertical stratification of chl a breaks down as hydrodynamic activity increases (stronger winds and current speeds) and microphytobenthos biomass decreases through reduced primary productivity, and increased senescence and grazing pressure. 


\section{Fate of microalgae}

Cycling of chl a within the sediments was clearly due to the production and degradation of the diatom community, illustrated by the close coupling between chl a and fucoxanthin with depth. Spring and autumn differences in chl $a$ on the Molenplaat can be explained by following the degradation of chl a to its various phaeopigment constituents: chlorophyllide a, phaeophorbide $a$, and phaeophytin $a$. Chlorophyllide a results from the loss of the phytol chain through chlorophyllase action, and may be present in senescent algae and nutrient-limited algae, as well as in copepod faeces (see Millie et al. 1993, Plante-Cuny et al. 1993). However, chlorophyllase activity can be activated during collection and processing of samples, and is sometimes considered to be an experimental artefact (see Millie et al. 1993). Phaeophorbide a and a-like pigments are widely considered to be the main degradation product of grazing (Hawkins et al. 1986, Bianchi et al. 1988, Klein \& Riaux-Gobin 1991, Barlow et al. 1993a), with phaeophytins indicators of cell senescence (Barlow et al. 1993a). Nevertheless, interpretation of chl a degradation pathways is made complex by the diversity of degradation pathways and rates due to environmental conditions, and multiple sources of material into the system including sinking of particles from the water column and production in situ (Sun et al. 1993). Several authors (Hurley \& Armstrong 1990, Sun et al. 1993) have noted that although degradation products can accumulate under anoxic conditions, they are fully degraded into colourless residues under oxic conditions.

On the Molenplaat, the total amount of phaeopigments differed spatially and temporally, and was influenced by the differences in sediment turnover and seasonal changes in benthic fauna activity. At all the sites examined, low phaeopigments in early spring were represented by approximately equal amounts of phaeophytins and phaeophorbides. The relative contribution of phaeophytins:chl a was greatest during the late autumn through winter months. As this is the period when biological activity is low, it would seem that a large proportion of the chl a is being degraded through photo-oxidation and cell senescence.

While there was a great deal of seasonality in the amount of degradation products at Site 2, Site 4 displayed a rapid turnover of algae throughout the year. Phaeopigments were much lower at the sandy sites than at the silty sites, and the vertical distributions were more homogenous. Accumulation of detrital material was prevented by high physical and biological mixing, which exposes the material to the oxic layers where pigments, and in particular phaeopigments, undergo rapid photo-oxidation to colourless residues.
The trend of more pronounced seasonality in phaeopigment content in stable silty sediments compared with coarser sediments has also been documented by Barranguet et al. (1997). Factors responsible for seasonal fluctuations include temperature, nutrient levels, irradiance, depth of photic zone, and grazing pressure (Lukatelich \& McComb 1986, Underwood \& Paterson 1993, Pinckney et al. 1995). The correlations between spatial distributions of chorophyll a and sediment variables were not valid for June and September combined. Greater silt and AFDW contents in the central region in September were not matched by greater chl a. Coincident with increased benthic fauna biomass, the amount of phaeophorbides increased throughout the spring to autumn period to become the dominant phaeopigment at all sites, but particularly the siltier sites. This highlights the importance of the biological community in chl a cycling (Gieskes \& Kraay 1986, Hawkins et al. 1986, RiauxGobin et al. 1987). For example, Bianchi et al. (1988) reported that phaeophorbides represented 40 to $60 \%$ of total phaeopigments in mesocosms containing the deposit feeders Macoma balthica and Leitoscoplos fragilis, but only 3 to $4 \%$ in controls without fauna. It appears that on the Molenplaat grazing pressure by the benthic community reduces algal biomass, resulting in the more homogenous distribution of algae across the Molenplaat during the autumn and winter.

\section{Import-export budget of primary producers on a tidal flat}

The microphytobenthos community, made up of diatoms, cyanobacteria, and euglenoids, plays a key role in tidal flat dynamics in estuaries. The cycling of microalgae both within tidal flats and between the tidal flat and overlying water column has considerable implications for both benthic and pelagic herbivores and in modifying sediment dynamics. Primary production of benthic microalgae living in the upper few $\mathrm{mm}$ of sediment can account for $-30 \%$ of an estuary's annual carbon budget (de Jonge \& Colijn 1994). This is particularly important in the winter and early spring when water column production is still limited by high turbidity.

Because of their close association with sediments, benthic microalgae are subjected to the same physical forces of currents and wave action. The presence of microphytobenthos as temporary members of the phytoplankton is well documented (Baillie \& Welsh 1980, de Jonge \& van Beusekom 1992, 1995), and they can contribute $-30 \%$ to water column chl a (de Jonge \& van Beusekom 1992). As a result of resuspension, algae are made available to local water column and 
benthic suspension feeders, or they can be transported several kilometres away. These losses may be replaced through in situ primary production or advection of microalgae from other sources.

Import and export of algae differs on a seasonal basis as the balance between physical and biological factors changes from winter to summer. HPLC analysis of chl a, degradation products, and accessory pigments in sediments has been used to identify the seasonal cycling of microphytobenthos both within the Molenplaat and between the Molenplaat and surrounding estuary. Before a numerical model of microphytobenthos dynamics on a tidal flat can be made, processes occurring within sediments and at the sediment-water interface have to be identified. Fig. 8 provides a conceptual model of the import and export of chl a biomass on the Molenplaat tidal flat.

\section{Summary}

The use of diagnostic pigments as markers for community composition and trophic fate applications should be carried out with caution because of their presence in several algal groups, and in amounts that may be influenced by trophic status and environmen-

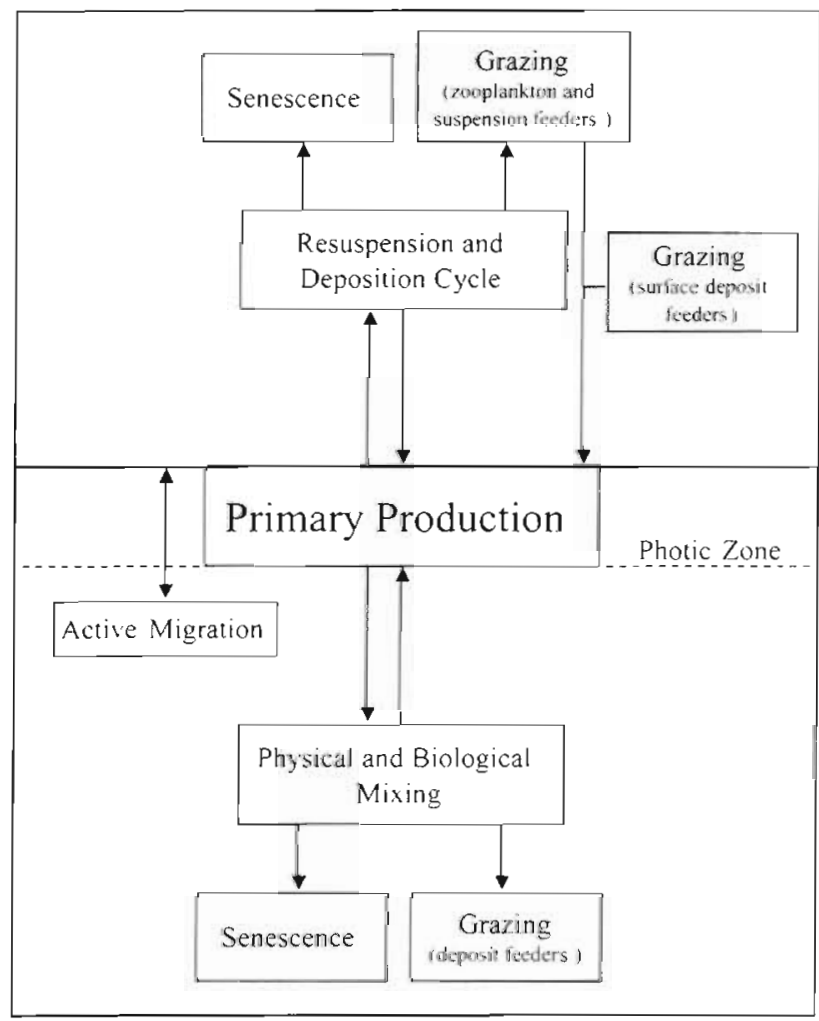

Fig. 8. Conceptual model of the cycling of microphytobenthos on a tidal flat tal conditions (Barlow et al. 1993b, Millie et al. 1993). Water column processes, such as photo-oxidation, cell lysis, and grazing may preferentially degrade pigments prior to their incorporation into sediments (Hurley \& Armstrong 1991). However, they do provide an insight into the cycling of material within tidal flat systems. On the Molenplaat, it appears that the sandy sites undergo rapid recycling of primary producers, with imports (in situ and deposited primary production) roughly balanced by exports (losses to grazing pressure, resuspension into the water column, and burial into sediment below the photic zone) for much of the year. At the silty sites, the import/export budget changes on a seasonal basis. During the spring and summer, these sites act as a sink for microalgae as both in situ and deposited biomass becomes incorporated into the sediment. As benthic fauna biomass increases during the summer and early autumn, grazing pressure acts to reduce microalgal biomass. This also has the effect of reducing sediment stability, and the sediment becomes more physically dominated, with rapid cycling of material in the upper few cm of sediment. Quantitative data on rates of processes can only really be provided by controlled experiments, where identified inputs of algal material are introduced to the system (e.g. Sun et al. 1993).

Acknowledgements. This paper is based on research within the ECOFLAT (Eco-Metabolism of a Tidal Flat) (contract ENV4-ct96-0216) project which is part of the ELOISE (European Land-Ocean Interactions Studies) Programme, jointly sponsored by the ENVIRONMENT and MAST programmes of the EU. This is ELOISE contribution No. 089.

\section{LITERATURE CITED}

Abele-Oeschger D (1991) Potential of some carotenoids in two recent sediments of Kiel Bight as biogenic indicators of phytodetritus. Mar. Ecol Prog Ser 70:83-92

Baillie PW, Welsh BL (1980) The effect of tidal resuspension on the distribution of intertidal epipelic algac in an estuary. Estuar Coast Mar Sci 10:165-180

Barlow RG. Mantoura RFC, Gough MA, Fileman TW (1993a) Phaeopigment distrubution during the 1990 spring bloom in the northeastern Atlantic. Deep-Sea Res I 40:2229-2242

Barlow RG, Mantoura RFC, Gough MA, Fileman IW (1993b) Pigment signatures of the phytoplankton composition in the northeastern Atlantic during the 1990 spring bloom. Deep-Sea Res II 40:459-477

Barranguet C, Herman PMJ, Sinke JJ (1997) Microphytobenthos biomass and community composition studied by pigment biomarkers: importance and fate in the carbon cycle of a tidal flat. J Sea Res 38:59-70

Bianchi TS, Dawson R, Sawangwong P (1988) The effects of macrobenthic deposit-feeding on the degradation of chloropigments in sandy sediments. J Exp Mar Biol Ecol 122:243-255

Bianchi TS, Findlay S, Dawson R (1993) Organic matter sources in the water column and sediments of the Hudson 
river estuary: the use of plant pigments as tracers. Estuar Coast Shelf Sci 36:359-376

Cadée GC, Hegeman J (1974) Primary production of the benthic microflora living on tidal flats in the Dutch Wadden Sea. Neth J Sea Res 8:260-291

Cariou-Le Gall V. Blanchard GF (1995) Monthly HPLC measurements of pigment concentration from an intertidal muddy sediment of Marennes-Oléron Bay, France. Mar Ecol Prog Ser 121:171-179

Colijn F, Dijkema KS (1981) Species composition of benthic diatoms and distribution of chlorophyll $a$ on an intertidal flat in the Dutch Wadden Sea. Mar Ecol Prog Ser 4:9-21

de Jonge VN, Colijn F (1994) Dynamics of microphytobenthos biomass in the Ems estuary measured as chlorophyll $a$ and carbon. Mar Ecol Prog Ser 104:185-196

de Jonge VN, van Beusekom JEE (1992) Contribution of resuspended microphytobenthos to total phytoplankton in the Ems estuary and its possible role for grazers. Neth $J$ Sea Res 30:187-200

de Jonge VN, van Beusekom JEE (1995) Wind- and tideinduced resuspension of sediment and microphytobenthos in the Ems estuary. Limnol Oceanogr 40:766-778

Fielding PJ, Damastra KStJ, Branch GM (1988) Benthic diatom biomass, production and sediment chlorophyll in Langebaan Lagoon, South Africa. Estuar Coast Shelf Sci $27: 413-426$

Gieskes WW, Kraay GW (1983) Dominance of Cryptophyceae during the phytoplankton spring bloom in the central North Atlantic detected by HPLC analysis of pigments. Mar Biol 75:179-185

Gieskes WW, Kraay GW (1986) Analysis of phytoplankton pigments by HPLC before, during, and after mass occurrence of the microflagellate Corymbellus aureus during the spring bloom in the open North Sea in 1983. Mar Biol 92:45-52

Graf G, Rosenberg R (1997) Bioresuspension and biodeposition: a review. J Mar Sys 11:269-278

Hawkins AJS, Bayne BL, Mantoura RFC, Llewellyn CA, Navarro $E$ (1986) Chlorophyll degradation and absorption through the digestive system of the blue mussel Mytilus edulis L. J Exp Mar Biol Ecol 96:213-220

Head EJH, Horne EPW (1993) Pigment transformation and vertical flux in an area of convergence in the North Atlantic. Deep-Sea Res II 40:329-346

Heip CHR (1988) Biota and abiotic environment in the Westerschelde estuary. Hydrobiol Bull 22:31-34

Hurley JP, Armstrong DE (1990) Fluxes and transformations of aquatic pigments in lake Mendota, Wisconsin. Limnol Oceanogr 35:384-398

Hurley JP, Armstrong DE (1991) Pigment preservation in lake sediments: a comparison of sedimentary environments in Trout Lake, Wisconsin. Can J Fish Aquat Sci 48:472-486

Jeffrey SW, Mantoura RFC, Wright SW (1997) Phytoplankton pigments in oceanography: guidelines to modern methods. UNESCO Publishing, Paris

King LL, Repeta DJ (1991) Novel pyrophaeophorbide steryl esters in Black Sea sediments. Geochim Cosmochim Acta 55:2067-2074

Klein B, Riaux-Gobin C (1991) Algal pigment diversity in coastal sediments from Kerguelen (sub-Antarctic Islands) reflecting local dominance of green algae, euglenoids and diatoms. Polar Biol 11:439-448

Kromkamp J, van Spaendonk A, Peene J, van Rijswijk $P$ Goosen N (eds) (1992) Light, nutrient and phytoplankton primary production in the eutrophic, turbid Westerschelde estuary (The Netherlands). In: JEEP92. Major biological processes in European tidal estuaries. MAST Report, NIOO-Yerseke, p 115-126
Krumbein WE, Paterson DM, Stal LJ (1994) Biostabilization of sediments. Bibliotheks und Informationssystem der Universität, Oldenburg

Leavitt PR, Carpenter SR (1990) Regulation of pigment sedimentation by photooxidation and herbivore grazing. Can J Fish Aquat Sci 47:1166-1176

Levinton JS, McCartney M (1991) Use of photosynthetic pigments in sediments as a tracer for sources and fates of macrophyte organic matter. Mar Ecol Prog Ser 78:87-96

Lorenzen CJ (1967) Determination of chlorophyll and phaeopigments: spectrophotometric equations. Limnol Oceanogr $12: 343-346$

Lukatelich RJ, McComb AJ (1986) Distribution and abundance of benthic microalgae in a shallow southwestern Australian estuarine system. Mar Ecol Prog Ser 27:287-297

MacIntyre HL, Geider RJ, Miller DC (1996) Microphytobenthos: the ecological role of the 'secret garden' of unvegetated, shallow-water marine habitats. I. Distribution, abundance and primary production. Estuaries 19:186-201

Mantoura RFC, Llewellyn CA (1983) The rapid determination of algal chlorophyll and carotenoid pigments and their breakdown products in natural waters by reverse-phase high-performance liquid chromatography. Anal Chim Acta 151:297-313

Millie DF, Paerl HW, Hurley JP (1993) Microalgal pigment assessments using high-performance liquid chromatography: a synopsis of organismal and ecological applications. Can J Fish Aquat Sci 50:2513-2527

NIOO Progress Report (1996) In: Middelburg J, Mooij W, van der Putten W (eds) Netherlands Institute of Ecology Progress Report. Ponsen \& looijen bv, Wageningen

Oppenheim DR (1988) The distribution of epipelic diatoms along an intertidal shore in relation to principal physical gradients. Bot Mar 31:65-72

Pinckney J, Paerl HW, Fitzpatrick M (1995) Impacts of seasonality and nutrients on microbial mat community structure and function. Mar Ecol Prog Ser 123:207-216

Plante-Cuny MR, Barranguet C, Bonin D, Grenz C (1993) Does chlorophyllide a reduce reliability of chlorophyll a measurements in marine coastal sediments? Aquat Sci 55: $19-30$

Riaux-Gobin C, Llewellyn CA, Klein B (1987) Microphytobenthos from two subtidal sediments from North Brittany. II. Variations of pigment compositions and concentrations determined by HPLC and conventional techniques. Mar Ecol Prog Ser 40:275-283

Sabbe K (1993) Short-term fluctuations in benthic diatom numbers on an intertidal sandflat in the Westerschelde estuary (Zeeland, The Netherlands). Hydrobiologia 269/270: $275-284$

Sabbe K, Vyverman W (1991) Distribution of benthic diatom assemblages in the Westerschelde (Zeeland, The Netherlands). Belg J Bot 124:91-101

Santos PJP, Castel J, Souza-Santos LP (1996) Spatial distribution and dynamics of microphytobenthos biomass in the Gironde estuary (France). Oceanol Acta 20:549-556

Stoetaert K. Herman PMJ (1995) Carbon flows in the Westerschelde estuary (The Netherlands) evaluated by the means of an ecosystem model (MOSES). Hydrobiologia 311:247-266

Stoetaert K, Herman PMJ, Kromkamp J (1994) Living in the twilight: estimating net phytoplankton growth in the Westerschelde estuary (The Netherlands) by means of an ecosystem model (MOSES). J Plankton Res 16:1277-1301

Sun MY, Aller RC, Lee C (1991) Early diagenesis of chlorophyll-a in Long Island Sound sediments: a measure of carbon flux and particle reworking. J Mar Res 49:379-401 
Sun MY, Lee C, Aller RC (1993) Anoxic and oxic degradation of ${ }^{14} \mathrm{C}$-labeled chloropigments and a ${ }^{14} \mathrm{C}$-labeled diatom in Long Island Sound sediments. Limnol Oceanogr 38: $1438-1451$

Sun MY, Aller RC, Lee C (1994) Spatial and temporal distributions of sedimentary chloropigments as indicators of benthic processes in Long Island Sound. $J$ Mar Res 52 : $149-176$

Sundbäck K (1984) Distribution of microbenthic chlorophyll-a

Editorial responsibility: Otto Kinne (Editor),

Oldendorf/Luhe, Germany and diatom species related to sediment characteristics Ophelia Suppl 3:229-246

Underwood GJC, Paterson DM (1993) Seasonal changes in diatom biomass, sediment stability and biogenic stabilization in the Severn estuary. J Mar Biol Assoc UK 73: $871-887$

Vernet M, Lorenzen CJ (1987) The relative abundance of phaeophorbide a and phaeophytin a in temperate marine waters. Limnol Oceanogr 32:352-358

Submitted: October 12, 1998; Accepted: January 1, 1999 Proofs received from author(s): April 21, 1999 